\title{
Ecological-Fishing Monitoring of Lake Fish in The Forested Area
}

\author{
Igor Semenovich Mukhachev* \\ Professor of Biological Sciences, Tyumen State University, Russia
}

*Corresponding author: Igor Semenovich Mukhachev, Professor of Biological Sciences, Professor at Tyumen State University, Gosagrouniversity of Northern Zauralya, Tyumen, Russia.

To Cite This Article: Igor Semenovich Mukhachev, Ecological-Fishing Monitoring of Lake Fish in The Forested Area. Am J Biomed Sci \& Res. 2020 7(1). AJBSR.MS.ID.001108. DOI: 10.34297/AJBSR.2020.07.001108.

Received: 漹 January 09, 2020; Published: 眥 January 23, 2020

\begin{abstract}
The article shows the role of the establishment of a method of surveillance-monitoring of ecological processes in Russia's fisheries lakes and names examples of ecological-fishery variability of lakes in the south of the West Siberian Plain, influenced by climate change dynamics. For this reason, it is recommended that a realistic assessment of the quality of the lake ecosystem used for the cultivation of sigfish, such as the main pastoral aquaculture sites of the Zauralye, be monitored.
\end{abstract}

Keywords: Monitoring of fisheries lakes; Increasing of fisheries productivity; Fisheries management; Optimization of management decisions on the fisheries management of lakes of the marine type (with depths of 2-4 m)

\section{Introduction}

One hundred years ago, M. P. Somov [ 1] laid the foundations of ecological and fisheries monitoring on lakes in the Northwest Russia in its fundamental work. It recommended the determination of the productivity dynamics of fisheries bodies for the collection of animal and plant species, which are based on the formation of fish products, which are entirely dependent on physical, climatic, floristic and other parameters of a particular body of water. The factor of productivity (fishing productivity) of the lake, which is changing over time, is considered to be the most important, and recommended to observe this process and the basis of dynamics of the changes of natural components, which will help to correct the practical actions of the fisherman's user of the water body. Thus, the dynamics of biologically-production aspects of the water body also depends on the economy-the production component-the fishery management, or the bonates, which can be increased significantly. At the beginning of the 20th century, [1,2] considered normal fish catches to 25 to $40 \mathrm{~kg} / \mathrm{ha}$, "high"-50 kg/ha and more, and "bad" annual catches of $20 \mathrm{~kg} / \mathrm{ha}$ and lower.

In southern Western Siberia and In these years, the lake fishery, based on shallow lakes exposed to periodic fluctuations, and hence the changes in the salinity and concentration of oxygen in the water, required specific changes based on landscaping techniques [3-5], stabilizing the ecological parameters of the lakes that are the sound fisheries of the administrative territory. At the same time, the Zonal Fisheries Science has intensified work on the introduction of new productive species of fish that were absent in the south of Ural and Western Siberia, which allowed the akchoir to aclite in local lakes in the local lakes, the Luga region of Luga, the karma (sasana), and then the [ [ ckarp]] [6,7]. 20 to $40 \mathrm{~kg} / \mathrm{ha}$. As an example of the practice of the Chelyabinsk fishermen's fishermen in the 1950s and 1960s, the system of fish nurseries and incubation workshops found that systematic tracking (monitoring) of the dynamics of ecological processes in fishery bodies by the integrated scientific and production laboratory can be managed by fisheries-efficiency in the lakes in use. A multiples analysis of hydrochemical, hydrobiological characteristics of the lake ecosystem provides a timely manoeuvre for the production of meliorative and lynch works on the same lakes of the enterprise.

Analysis of the development of the Chelyabinsk fishery in 19491963. has shown that fish-axing activities, with their extensive implementation, have increased the commercial productivity of the existing lake fund three times-from $18-25 \mathrm{~kg} / \mathrm{ha}$ to $55-70 \mathrm{~kg} /$ ha, reaching maximum catches (170-180 kg/ha) per year [8]. It was the ecological-fishery monitoring of the main mass of fish 
reservoirs and the rapid application of the necessary melioration and specified fish planting in accordance with the real feed base and ecological conditions ensured the improvement of the fishing productivity of the Chelyabinsk fishermen.

A new impetus to the effectiveness of environmentalmanagement monitoring as a basis for economic development and, then, further development of commercial fish farming. Therefore, the increase of each hectare of the "blue nib'a" represents us the perennial practice of the Kazan lake fish, called "Kazanskaya Fish". Rybkhoz was created in 1968g. It was preceded by two years of comprehensive examination of the Kazan district lake fund, which had a total water area of 10.0 thousand tons. -Io. Out of a total of 90 small lakes, only 24 lakes were included in the fish, with a total area of 6,372 hectares. In 10 lakes, using landscape conservation principles, low-pressure (height $1 \mathrm{~m}$ ) dams and water regulators to launch extreme floods were built to accumulate spring floods.

Hydrobiologists and fishers have established that 490 tons of fish and carp can be grown annually in this area. Prior to the organization of the fish, local consumer cooperation on the lakes in the Kazanskai region was fishing of tuna with an average annual total catch of carasers, carrots, perch, and pike fish, 50 to 60 tonnes, therefore, the fisheries management fee was criticized. However, in 1972. The fish-breeders provided the non-water crews with the catch of valuable fish and carp in the amount of 540 tons, which is more than that of the Ecological and Fisheries Project [9]. For 40 years, the amount of fish grown per 6 thousand tons per year. In the current period of 2015 -2019s, the specialists of CJSC "Kazanskaya" fish, perfecting the technology for the production of fish and karp, annually produce 900-1000 tons of high-quality fish, or $150-170 \mathrm{~kg} / \mathrm{ha}$, which is 5 to 6 times more than in traditional fish fishery. This success is accompanied by continued cooperation with zonal fisheries science and the monitoring of the level of the lake regime, the mineralization of water and the development of self-renewable fodders for fish. The performance of the fishery and the management of the fisheries services of the endowed lakes is usually greater than that of non-borrowing.

At the same time, integrated environmental and fishery research was conducted on the basis of monitoring in the area of the lake forest steppe, within the Priyshimsky plains, and the degree (bonito) of their suitability for a process in a particular period of time was determined. This work is necessary because of the constant changes in the water depth of the southern Zaural region with lakes experiencing significant swings in their depth, and as a consequence-drastic changes in the chemical composition of water to extreme conditions (values) that are incompatible with the life of all freshwater fish. Consequently, for a number of reasons, not every lake can be used for a single year, and even more so for a longterm production of commercial fish. 1) in 2018-2019. is not allowed to carry fish on it, because the summer warming of the water stimulates destructive bioecological processes and the emergence of moronic phenomena based on the lack of oxygen in the water. The winter process in the shallow lake completely excludes fish and fishes for fish invertebrates-zooplankton and zoobentos (Figure 1).

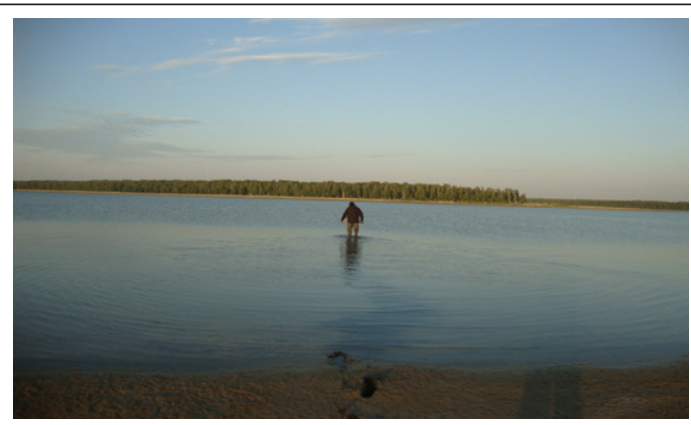

Figure 1: The actual depth of Lake Shtanovo of Safakulevsk district of Kurgan area in June $2019 \mathrm{~g}$.

In view of the frequency of fluctuations in the level of lakes in the south of West Siberian Plain [10,11], and the emerging natural conditions (factors) of the region, the zonal fisheries management of the region were developed and recommended by lake merchandise trade khozors of the region located in the steppe of the Priyshimsky Plain of the region of the lake. They provide a realistic assessment of the environmental and production capabilities of each particular lake of forest steppe Zauralye, which is used for the production of commercial fish in points [12]. Studies have found that all the wooded lakes of the Priishimsky Zauralye-type lake may be subdivided into five classes with their main characteristics (Table 1).

Table 1: A lake fishery used for the production of commercial fish and its main characteristics.

\begin{tabular}{|c|c|}
\hline Lake class and its characteristic features & Class Ballroom \\
\hline 1 the class & \\
\hline $\begin{array}{l}\text { Periodically seafloor lakes with medium depths of } 3.3 \text { to } 3.8 \mathrm{~m} \text {, high growth of zooplankton (more than } 5 \mathrm{~g} / \mathrm{m} 3 \text { ) and } \\
\text { zoobentos (more than } 50 \mathrm{~g} / \mathrm{m} 2 \text { ) during the growing season. The sum of the main ions of water is } 0.8-3.0 \mathrm{~g} / \mathrm{dm} 3 . \text { The water } \\
\text { index } \mathrm{ClNa}, \mathrm{SNa} \text {, CCa. Less than } 5 \% \text { of hard macrophite can be reachable. Total fish catches of fish more than } 200 \mathrm{~kg} / \mathrm{ha} \text { per } \\
\text { year. A 2-3-year-fanged fish can be raised }\end{array}$ & More than 85 \\
\hline
\end{tabular}




\section{2 the class}

The sea lakes with hot spots (15 -20\% of the water area) of increased oxygen in water in winter (more than $2 \mathrm{mg} / \mathrm{m} 3$ ). Average depth of 2.6-3.3 m. The zooplankton biomass is 3.6-5.0 g/m3, zobentos $36-50 \mathrm{~g} / \mathrm{m} 2$. Water mineralization-total ions0.8- $3.0 \mathrm{~g} / \mathrm{dm} 3$ Index of water $\mathrm{ClNa}, \mathrm{SNa}, \mathrm{CNa}$. The ability to reach $10 \%$ by hard macrophites. Total catches of farmed fish ranged from 130 to $200 \mathrm{~kg} / \mathrm{ha}$ a year (one year off).

\section{3 the class}

The lakeside lakes. The oxygen content of the ice is $1-1.2 \mathrm{mg} / \mathrm{m}^{3}$, between 0.5 and $0.7 \mathrm{mg} / \mathrm{dm} 3$. Interoperability of macrophites up to $20 \%$ of the water area. Mineralization of water (sum of main ions) $0.3-5 \mathrm{~g} / \mathrm{dm} 3$. The water index ClNa, SNa. The average depth of the lake is 2-2.5 m. Biomass of zooplankton during open water period 2.6-3.5 g/m3, zoobenthos-15-35 $\mathrm{g} / \mathrm{m} 2$ Total catches of grown fish are $80-130 \mathrm{~kg} /$ ha per year (single year).

\begin{tabular}{|c|c|}
\hline 4 the class & \\
\hline $\begin{array}{l}\text { Marine lakes with development of macrophite (hard } \mathrm{x} \text { and soft) up to } 40 \% \text { of the water area. Mineralization from } 1 \text { to } 6 \text { to } 7 \\
\mathrm{~g} / \mathrm{dm} 3 . \text { Oxygen shortage of ice up to } 100 \% \text {. The average depth of the lake is } 1.3 \text { to } 1.8 \mathrm{~m} \text {. Biomass zooplankton } 2-2.5 \mathrm{~g} / \mathrm{m} 3 \text {, } \\
\text { zoobenthos-from } 6 \text { to } 14 \mathrm{~g} / \mathrm{m} 2 \text {. Farmed fish caught between } 35 \text { and } 50 \mathrm{~kg} / \mathrm{ha} \text { per year (single year). }\end{array}$ & $30-49$ \\
\hline 5 the class & \\
\hline $\begin{array}{l}\text { Marine lakes with varying degrees of macrophite (surface and loaded) at an average depth of } 1.2 \text { to } 1.3 \mathrm{~m} \text {. The water } \\
\text { mineralization is } 7-12 \mathrm{~g} / \mathrm{dm} 3 \text {. The winter lake will be frozen at } 50-60 \% \text { of the water area. No oxygen. Winter is the day of } \\
\text { sulfide layer, and the summer is the active allocation of methane, carbon dioxide and the constant smell of hydrogen sulfide. } \\
\text { In summer, the deaths of all fish and other fish species are frequent. Biomass of zooplankton during open water can reach } \\
2-" . \% \mathrm{~g} / \mathrm{m} 3 \text { and zoobenthos up to } 5-6 \mathrm{~g} / \mathrm{m} 2 \text {. Total catches of farmed fish do not exceed } 20-30 \mathrm{~kg} / \mathrm{ha} \text { per year (one year off). }\end{array}$ & To 30 \\
\hline
\end{tabular}

The use of the characteristics of the table allows a better assessment of the actual characteristics of any lake of the steppe zone of Zauralye, considered as the production base of "fish section" in the decision on the selection of the technology of the river-reclamation process for many years-as the result of the tender solver of water. It is also important to take into account the dynamics of water mineralization and its gas treatment. In the territory of the region, in accordance with the ecological conditions of the geographical landscape, the main form of fish farming on the basis of the sea-type lakes may be the technology of one-yearsummer (growing) pelleting (s), therefore the continuous fouryear regime for the production of commercial fish on most lakes of Zamurai is not realistic.

The Ministry of Agriculture of the Russian Federation issued an order on March 15, 2017. No. 124 "On approval of the methodology for determining the minimum amount of aquaculture facilities to be produced and (or) to contain, grow, and to release into a water object and to remove from the water object within the boundaries of a fish section", provides for a regional approach to the implementation of aquaculture on local bodies, indicating an average annual output (catch) of $25 \mathrm{~kg} / \mathrm{ha}$ in Kurgan area. This is a completely objective measure, taking into account the actual indicators of the development of the natural corm base of local water bodies with tense ecological situation (lack of oxygen in water; high and high mineral water mineralization; and water). However, for the conditions of the Kurgan region, this Order does not provide for the foresight of fish (aquaculture) in hypersaline lakes, as differentiated in the conditions of the Astrakhan region and the Republic of Kalmykia. This procedure is also necessary for the lake fund in the south of Zauralye and Western Siberia.

The current practice of marketed fish farming in 2010-2019g. Objectively demonstrated that ignoring natural natural climatic factors, characteristic of some $40-45 \%$ of the Kurgan region of the
Kurgan region, with saltwater and dramatically changing depths ( $1 \mathrm{~m}$ and more) for several months, has a number of negative consequences:

a) waste of expensive fishery material (larvae, mobs, etc. (a) All fish in the shallow-water lake, with highly salinized water, resulting in the rapid or slow death of all

b) causing economic damage to users of extreme lakes, which are only occasionally suitable for fish, because of climatic dynamics that increase or reduce the lake level and to mineralization of their waters, to which the young valuable fish have been given full time

c) The lack of confidence in the practices of the fisheries sector in the conduct of the State regulatory and supervisory bodies and services in the Russian Federation

d) Real departure from objectively needed irrigation activities by hydro-technical measures that increase the productivity of local water bodies that have the potential to "produce" organic "organic produce", which will increase the balance of "food security" of the region of Zauralye.

The Ecological-Fisheries Management Monitoring of the Region of the Zauralya region for the cultivation of sig fish (peas, moksun, chir, hybrids) has recorded the "infestation" of the fish-eating cormorant arriving from the south at the beginning of August by large steels, ravaged by fish farmers from growing valuable food products for the population of the region. This problem should be solved at the State level of the Russian Federation (Figure 2). The thousandth of the cormorants (like the wolves in the agricultural animals) play the role of active predators specializing in the eating of commercial egrouletes and other sigfish (many hundred tons annually), ravaging the lakes of Tyumen and Kurgan regions. The clans began to fly from the south when the south of Zauralye and Western Siberia began to grow horny fish. 


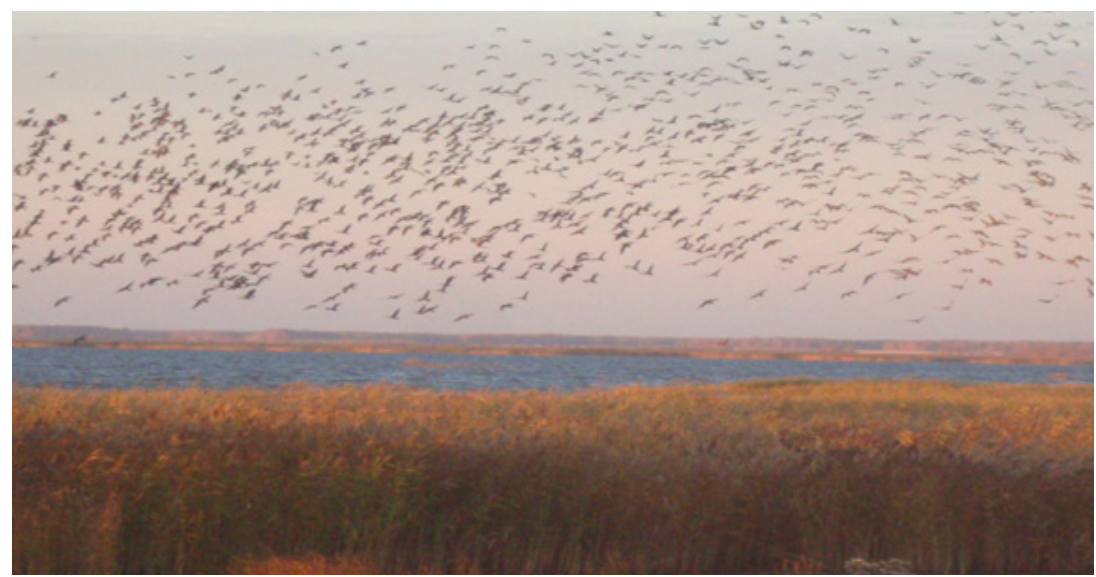

Figure 2: Zhuravl Lake, Kurgan Oblast-September 28, 2018. (photo: Mukhachev I.C.).

\section{References}

1. MP Somov (1920) Basic Principles of Lake Congland rigging. -Izzz. Ood Fish farming and research, etc. 1, P.2, 1920: 131-336.

2. Domrachev PF (1922) Russian Hydrological Institute 4: 1-43.

3. BerezovskyA I (1935) Melioration in the fisheries sector, VKI M, Russia, 1-77.

4. Cherfaas BI (1934) Foundations of Sustainable Lake Management-M: KOZ, Japan, 1-108.

5. (1932) Piers of PL Investigation and use of water bodies of Siberia. Isd to "Soviet Asia"1-175.

6. (1964) Tyrone M D Akklimatization and the growing of valuable fish species as a method for increasing the fishery productivity of the Ural waters. Uralski's work, yugoslavr, 13-18.

7. Yoganzen BG, Petkevich AN, Nesterenko NP, Nesterenko NV, Podlesny AV, et al. (1972) Akklimatization and the breeding of valuable fish in natural reservoirs and reservoirs in Siberia and Ural-Sverdlovsk: MediumCentral Asia, 1-288.

8. Mukhachev IS (1965) Rybiculture changes the structure of the fishery. Fisheries 12:14-16.

9. Burdiane BG (1975) Mukhachychev IS in the lakes (experience of Kazan experiment and demonstration lake). M Pritchface 1-63.

10. (1950) AV Internal fluctuations in the level of steppe lakes of Western Siberia and North Kazakhstan and their dependence on climate. The work of the lake science lab. M-LIzd-in the Academy of Sciences of the USSR, Sovereign, 28-129.

11. (1989) ABInternal volatility of the components of the general moisture content. L: Science, 1969: 1-246.

12. MO Agropromiz, USA. 1-161. 